\title{
Acute Infantile Hemorragic Edema with Penile Involvement
}

\author{
Öner Özdemir ${ }^{1}$, Yiğit Mustafa Ertunç ${ }^{2}$
}

${ }^{1}$ Sakarya Üniversitesi Tip Fakültesi, Eğitim ve Araștırma Hastanesi, Çocuk Sağlı̆̆ı ve Hastalıkları Anabilim Dalı, Alerji ve İmmünoloji Bilim Dal, Sakarya, Türkiye

${ }^{2}$ Sakarya Üniversitesi Tip Fakültesi, Eğitim ve Araştırma Hastanesi, Çocuk Sağhlğı ve Hastalıkları Anabilim Dalı, Sakarya, Türkiye

Yazışma Adresi / Correspondence:

\section{Öner Özdemir}

Division of Allergy and Immunology, Department of Pediatrics, Faculty of Medicine, Sakarya University, Research and Training Hospital of Sakarya University Adnan Menderes Cad., Sağlık Sok., No: 195, Adapazarı, Sakarya, Turkey

T: +902644445400 E-mail: ozdemir_oner@hotmail.com

Geliş Tarihi / Received : 09.02.2019 Kabul Tarihi / Accepted : 03.04.2019

Orcid:

Öner Özdemir https://orcid.org/: 0000-0002-5338-9561

Yiğit Mustafa Ertunç https://orcid.org/: 0000-0002-0920-7652 


\section{Acute Infantile Hemorrhagic Edema} with Penile Involvement

14-month old male patient was presented to Pediatric emergency department because of eruption which started from upper extremities and spread to the body. The patient's anamnesis revealed subfebrile fever and upper respiratory tract infection symptoms lasted 3 days. Physical examination showed edema and ecchymotic purpura in the upper/lower limbs, genital and gluteal regions and in the face. Laboratory test results demonstrated WBC:

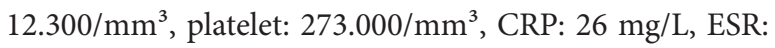
$20 \mathrm{~mm} /$ hour. Biopsy findings was consistent with leukocytoclastic vasculitis. The patient was consulted Dermatology and Pediatric Allergy and Immunology Departments on the 4th day of admission, and they confirmed that lesions were matching with acute infantile hemorrhagic edema (AIHE). On the 6th day of admission penil edema developed (figure I), and dermatologist recommended daily fifteen minutes dressing with $\% 2$ boric acid solution on penil area and afterwards applying zinc based cream. On the 7th day of admission, penil edema decreased (figure II) and on the 8th day it was completely resolved (figure III). AIHE is an uncommon benign form of leukocytoclastic vasculitis and usually seen between 4 and 24 months of age. ${ }^{1}$ Classical triad are purpuric skin lesions, edema and fever. Round shaped skin lesions are usually seen on the face and limbs but rarely seen in genital area. ${ }^{2}$ Skin lesions disappear spontaneously within 1-3 weeks without mucosal and visceral involvement. Although there is no internal organ involvement, physicians should keep in mind that AIHE very rarely manifests with penile lesions.

\section{Informed Consent}

Written informed consent was obtained from the parents of the patient who participated in this study.

\section{Conflict of Interest}

Authors have no conflict of interest to declare.

\section{Financial Disclosure}

The authors declared that this study has received no financial support

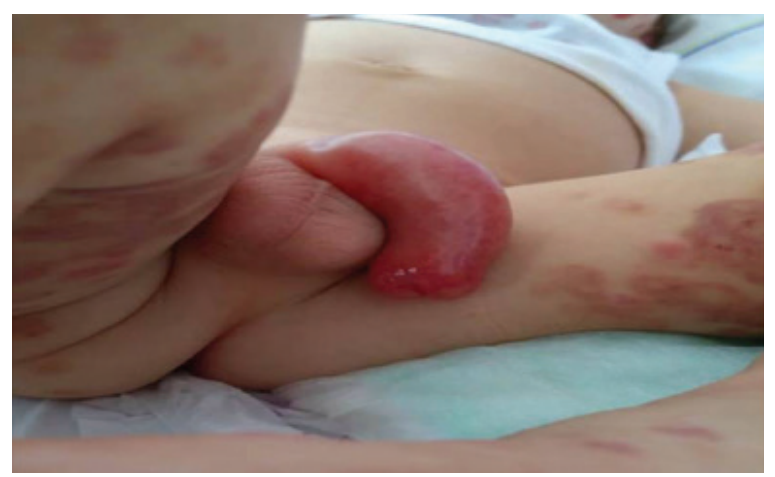

Figure I. Penile edema development in our patient on the 6th day of admission.

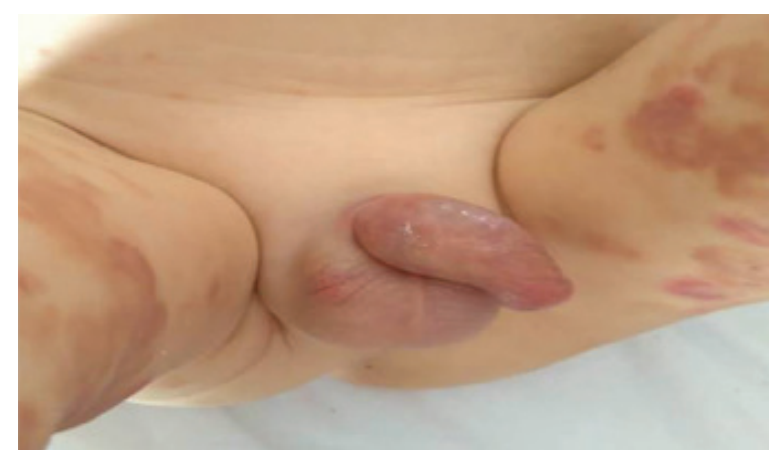

Figure II. Decreased penile edema on the 7th day.

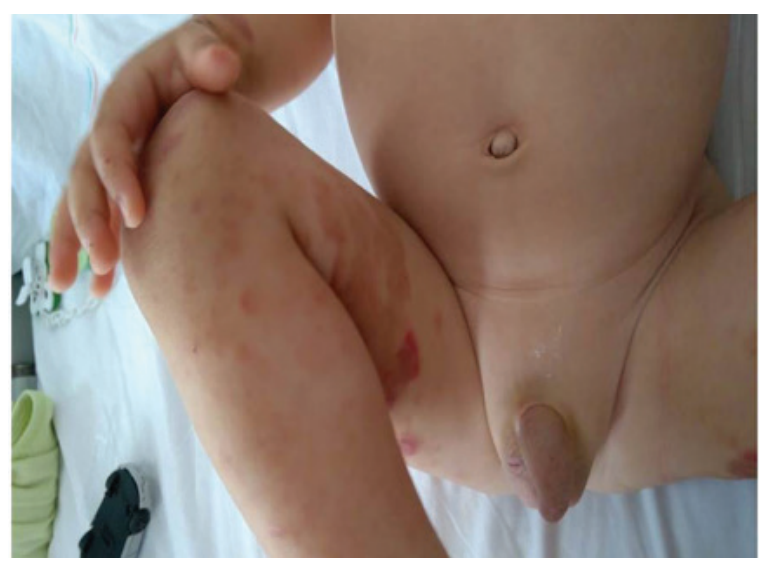

Figure III. Penile edema was completely resolved one day later. 
Sakarya Med J 2019;9(2):366-368

ÖZDEMIR et al. Acute Infantile Hemorragic Edema with Penile Involvement

\section{References}

1. Jindal SR, Kura MM. Acute hemorrhagic edema of infancy-a rare entity. Indian Dermatol Online J. 2013; 4(2): 106-108.

2. Poyrazoğlu HM, Per H, Gündüz Z, et al. Acute hemorrhagic edema of infancy. Pediatr Int. 2003;45(6):697-700 